\title{
Comparative study of test kits for measurement of rheumatoid factors by the latex fixation test
}

\author{
F Klein, M B J A Janssens, L K J van Romunde, G A M Eilers
}

\begin{abstract}
The performance of 14 test kits for the measurement of rheumatoid factors by the latex fixation test was investigated; all results were expressed in IU/ml. Reproducibility and properties of control sera were also studied. It was found that half of the kits did not satisfactorily detect rheumatoid factor levels lower than $25 \mathrm{IU} / \mathrm{ml}$. Most kits performed reasonably well in practice. Positive control sera only rarely met strict requirements. The relative costs did not always have a clear correlation with the quality of the results. The variation caused by differences between kits became acceptable when the results were expressed in $I U / \mathrm{ml}$.
\end{abstract}

The latex fixation test was developed in 1956 by Singer and Plotz ${ }^{1}$ as an alternative to the Waaler-Rose test. The test is usually carried out with human gammaglobulin (IgG) as a substrate. Titration can be used in the test to give quantitative results or the test carried out to give just a positive or negative result. Detailed descriptions of the method have been given by Singer ${ }^{2}$ and by Valkenburg. ${ }^{3}$ The biochemical background of the latex fixation test has been investigated by Klein et al. ${ }^{4}$

Although methods like nephelometry and enzyme linked immunosorbent assay (ELISA) have recently gained ground, the latex fixation test is still in routine current use in many laboratories. ${ }^{5}$ The importance attached to this test is reflected by the large number of commercial kits currently available-13 in the Netherlands by the end of 1986 .

The wide variation in results obtained with different test kits became evident in a standardisation study published in 1987.6 It was shown that the spread could be considerably reduced by expressing the results in $\mathrm{IU} / \mathrm{ml}$ instead of in titres. The contribution of differences between test kits to the overall variation between laboratories was not evaluated.

Our study evaluates 14 different latex fixation test kits for reproducibility, limit of detection, general practicability, and influence on interlaboratory comparability of the results.

This study was carried out under the mandate of the Dutch coordination committee for quality control of clinical laboratory research. A report of this study, in Dutch, with a limited circulation appeared in 1988.*

\section{Methods and materials}

Thirteen commercial latex agglutination kits (table 1) were purchased from manufacturers that had previously been informed about the aim of the study. This was one of the conditions necessary for obtaining their cooperation. One 'experimental kit' or rather method, in limited routine use in some laboratories in the Netherlands, was also included in the study. Details of this method, which comprises the preparation of a new type of polystyrene latex, have been published previously. ${ }^{7}$

Test sera were prepared by mixing patients' sera so that 14 pools of differing rheumatoid factor levels were obtained. The serum samples were selected by screening in an IgM-ELISA and a latex fixation test. The values obtained in these tests were not used as target values (see below-'General design of tests'). Six additional test sera were consistently negative in both screening tests. The use of pools makes it impossible to relate the results to individual clinical symptoms. This design was chosen in order to introduce the necessary diversity.

\section{GENERAL DESIGN OF TESTS}

Rheumatoid factor tests were performed in three rounds by four laboratories experienced in rheumatoid factor serology. In each of the rounds the 20 test sera were offered in a different order unknown to the laboratories. All tests were performed exactly according to the manufacturers' directions. All serum samples had to be titrated until negative, and therefore only test kits allowing titration were considered. The Dutch national reference serum preparation (calibrated in IU, see Klein and Janssens ${ }^{6}$ ) was measured three times in each test run. The results were expressed in $\mathrm{IU} / \mathrm{ml}$ using the median of the three results in the calculations. To reduce work load the kits were distributed among the laboratories so that each kit was investigated by three laboratories. This design results in an incomplete matrix for analysis of variance (see under 'Statistical methods').

As none of the methods in this study could be considered to be a reference method no target values were established in the test sera.

A questionnaire was used to assess the practicability of the procedures as described by the manufacturers. Questions were asked about readability of the test, clarity of the manufacturers' instructions, ease of handling, working 
Table 1 Properties of the 14 test kits used for the latex fixation test

\begin{tabular}{|c|c|c|c|c|c|c|c|}
\hline Name & Code & $\begin{array}{l}\text { Detection limit } \\
\text { as read from } \\
\text { graphs* }\end{array}$ & $\begin{array}{l}\text { \% Positivity } \\
\text { found in } \\
\text { control sera }\end{array}$ & $\begin{array}{l}\text { Neg. scores } \\
\text { in non-neg. } \\
\text { test sera }(\%)\end{array}$ & $\begin{array}{l}\text { Reproducibility } \\
\text { (SD in dilution } \\
\text { steps) }\end{array}$ & $\begin{array}{l}\text { General } \\
\text { practicabilityt }\end{array}$ & $\begin{array}{l}\text { Relative } \\
\text { cost } \neq\end{array}$ \\
\hline $\begin{array}{l}\text { V-trend kit RF, VT-techn Inc } \\
\text { Biokit, Reumagen AR } \\
\text { Bacto rheumatoid titration test, Difco } \\
\text { RA latex, Mercia Diagnostics } \\
\text { Rapitex RF, Hoechst Behring } \\
\text { Rheumafaktor Rörchentest, Roche } \\
\text { RA test reagents, Cooper Biomedical } \\
\text { Rheuma-Fac RA test latex, ICL Scientific } \\
\text { Rheumatoid factor latex agglutination, } \\
\text { Diagnostics Pasteur } \\
\text { Latex Norde (see ref 7) } \\
\text { Nycotest RF latex, Nyegaard } \\
\text { Ortho RA test, Ortho Diagnostic Systems } \\
\text { RF latex quicktest, Human Biochemica } \\
\text { Rheuma-Wellcotest, Wellcome }\end{array}$ & $\begin{array}{l}\text { VT } \\
\text { BI } \\
\text { DI } \\
\text { ME } \\
\text { RA } \\
\text { RO } \\
\text { HY } \\
\text { IC }\end{array}$ & $\begin{array}{l}- \\
- \\
\pm \\
- \\
+ \\
\pm \\
+ \\
+\end{array}$ & $\begin{array}{r}86 \\
67 \\
100 \\
86 \\
43 \\
100 \\
100 \\
100\end{array}$ & $\begin{array}{l}43 \\
39 \\
33 \\
38 \\
20 \\
33 \\
25 \\
17\end{array}$ & $\begin{array}{l}0.72 \\
0.90 \\
1.24 \\
1.07 \\
1.01 \\
0.98 \\
1.31 \\
1.18\end{array}$ & $\begin{array}{l}+ \\
+ \\
- \\
+ \\
+ \\
+ \\
\pm \\
+\end{array}$ & $\begin{array}{l}1.63 \\
0.84 \\
1.00 \\
0.81 \\
0.95 \\
1.81 \\
1.41 \\
1.81\end{array}$ \\
\hline
\end{tabular}

$*+=$ below $5.5 \mathrm{IU} / \mathrm{ml}$, always above average; $\pm=$ below $5.5 \mathrm{IU} / \mathrm{ml}$, sometimes above average; $-=$ below $5.5 \mathrm{IU} / \mathrm{ml}$, always under average

$t+=$ good; $\pm=$ moderate, $-=$ bad.

Fraction of median cost of materials per dilution in Dutch guilders (1986)

Not commercially available.

time needed for each kit, amount of reagents supplied (sufficient or not), and other relevant observations.

\section{STATISTICAL METHODS}

All calculations were performed on the standardised values - that is, after expression in $\mathrm{IU} / \mathrm{ml}$. The values in IU were transformed to logarithms by the formula: $\log _{2}$ reciprocal dilution $=\log _{2} \mathrm{IU} / \mathrm{ml}-\log _{2} 0.39$. A level of 0.39 $\mathrm{IU} / \mathrm{ml}$ (one dilution below the lowest level found) would thus be transformed to 0 , but for practical reasons it was put at 1 . This comprises all values $\leqslant 0.78 \mathrm{IU} / \mathrm{ml}$, which is in fact the lowest value measured in our experiments.

The design adopted here is incomplete as not every laboratory investigated every kit. This may have caused some ambiguity in the analysis of variance, which might be dependent on the sequence of calculation. To investigate the reproducibility of the kits standard deviations were calculated over three days for every combination serum-kit-laboratory. These SDs were averaged over the laboratories and over the serum samples. The resulting figures were used as a measure of intrakit variability (table 1 ).

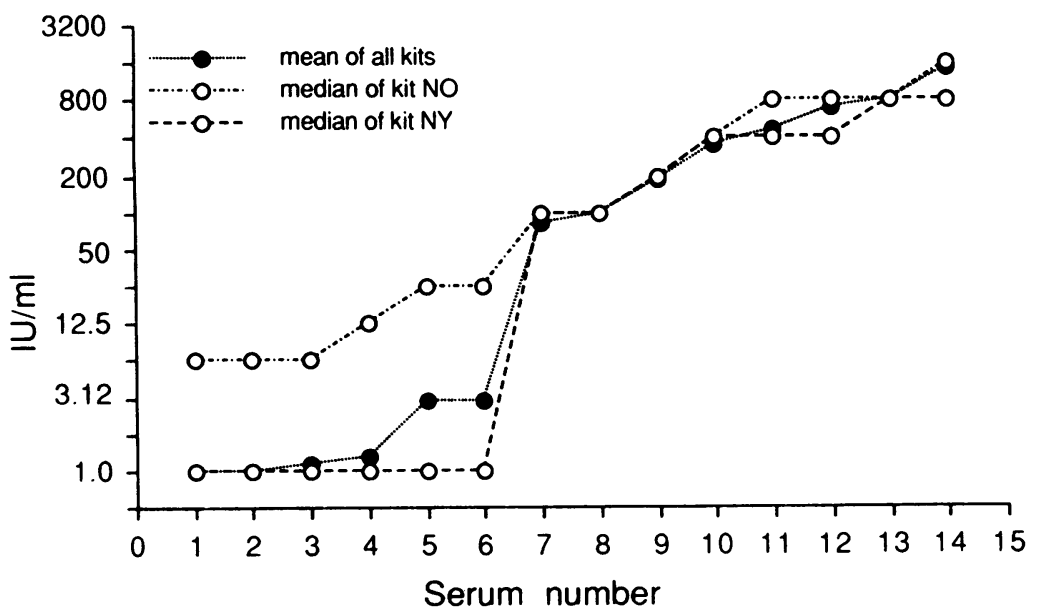

Comparison of the median score of two latex test kits in 14 serum samples with the mean scores of 14 kits in the same samples. The serum number refers to the 14 positive serum pools, which have been arranged consecutively in order of increasing average IU level.
In addition, an analysis of variance was carried out on the mean values over three days, using a general linear model. ${ }^{8}$ To estimate the contribution of separate variables to the overall variance its components were calculated by the method of Hicks. ${ }^{9}$ In these calculations it is important whether a variable is considered as a fixed or a random factor. Serum samples and kits were regarded as fixed because rheumatoid factor levels in serum pools were chosen in advance in order to cover the whole range of interest, and the kits comprised all kits available in the Netherlands at the time of the experiment. Neither can be regarded as a random sample. The laboratories and replicate tests were regarded as random.

The detection limits were estimated in three ways. Firstly, a graphical method was developed as follows. The median scores of each individual kit for each serum were plotted together with the mean values of all kits for each serum (all in $\mathrm{IU} / \mathrm{ml}$ ). Medians were taken for individual kits instead of means because most distributions of individual values in the lower region resulted in a mean of one high value and many zero scores. The figure illustrates the procedure for two kits - one with a good (NO) and one with a poor (NY) performance for the lower values. For each kit under investigation a line can be drawn connecting all values specific for this kit. If the graph for an individual kit runs above the means the kit is a good one. The graphs show a gap between 5.5 and $60 \mathrm{IU} / \mathrm{ml}$. The variation in the $5.5 \mathrm{IU} / \mathrm{ml}$ region is so large that the upper limit of its range touches the lower limit of the $60 \mathrm{IU} / \mathrm{ml}$ range (data not given). Thus the gap is bridged because several kits do in fact score values between 5.5 and $60 \mathrm{IU} / \mathrm{ml}$ in serum samples where other kits find lower (or sometimes higher) values.

A second way of looking at detection limits is by taking the lowest readings (in $I U / \mathrm{ml}$ ) ever made by each kit in any laboratory when all test sera are taken into account (see table 2).

Finally, the detection limits were estimated by calculation for each kit how many IU/ml would correspond with an agglutination in the first dilution only. Expressed mathematically the detection limit then equals $200 / 2^{n-1}$, where 
Table 2 Detection limit of kits as calculated by different methods

\begin{tabular}{|c|c|c|c|c|}
\hline Code & $\begin{array}{l}\text { According to } \\
\text { manufacturers } \\
\text { in IU/ml }\end{array}$ & $\begin{array}{l}\text { Owon readings } \\
\text { from reference serum } \\
\text { in } I U / m l\end{array}$ & $\begin{array}{l}\text { Own readings } \\
\text { from test sera } \\
\text { in } I U / m l\end{array}$ & $\begin{array}{l}\text { Score in } \\
\text { graphst }\end{array}$ \\
\hline $\begin{array}{l}\text { VT } \\
\text { BI } \\
\text { DI } \\
\text { ME } \\
\text { RA } \\
\text { RO } \\
\text { HY } \\
\text { IC } \\
\text { IN } \\
\text { NO } \\
\text { NY } \\
\text { OR } \\
\text { HU } \\
\text { WE }\end{array}$ & $\begin{array}{l}20 \\
20 \\
10\end{array}$ & $\begin{array}{l}50 \\
50 \\
6 \cdot 25 \\
50 \\
25 \\
25 \\
25 \\
25 \\
25 \\
0 \cdot 78 \\
100 \\
50 \\
50 \\
25\end{array}$ & $\begin{array}{l}50 \\
25 \\
12 \cdot 5 \\
25 \\
12 \cdot 5 \\
12 \cdot 5 \\
3.12 \\
25.5 \\
12.5 \\
1.56 \\
50 \\
25 \\
25 \\
12.5\end{array}$ & $\begin{array}{l}- \\
\overline{-} \\
\pm \\
+ \\
+ \\
\pm \\
+ \\
+ \\
\pm \\
+ \\
- \\
- \\
-\end{array}$ \\
\hline
\end{tabular}

${ }^{*}$ See table 1 .

$t+=$ always above average, below $5.5 \mathrm{IU} / \mathrm{ml} ; \pm=$ sometimes above average, below $5.5 \mathrm{IU} / \mathrm{ml}$; $-=$ always under average below $5.5 \mathrm{IU} / \mathrm{ml}$.

Table 3 Results of the analysis of variance

\begin{tabular}{|c|c|c|c|c|c|}
\hline & $\begin{array}{l}\text { Degrees of } \\
\text { freedom }\end{array}$ & $\begin{array}{l}\text { Mean } \\
\text { squares }\end{array}$ & $F$ & p Value & $\begin{array}{l}\text { Variance } \\
\text { component }\end{array}$ \\
\hline $\begin{array}{l}\text { Sera } \\
\text { Kits } \\
\text { Lab } \\
\text { Sera } \times \text { kit } \\
\text { Sera } \times \text { lab } \\
\text { Kit } \times \text { lab } \\
\text { Sera } \times \text { kit } \times \text { lab } \\
\text { Error (replicates) }\end{array}$ & $\begin{array}{r}13 \\
13 \\
3 \\
169 \\
39 \\
25 \\
325 \\
1176\end{array}$ & $\begin{array}{r}1980 \cdot 5 \\
42 \cdot 9 \\
48 \cdot 0 \\
5 \cdot 2 \\
5 \cdot 2 \\
5 \cdot 6 \\
1.77 \\
1.80\end{array}$ & $\begin{array}{c}380.9 \\
7.7 \\
26.7 \\
2.94 \\
2.89 \\
3 \cdot 11 \\
0.98\end{array}$ & $\begin{array}{l}<0.001 \\
<0.001 \\
<0.001 \\
<0.001 \\
<0.001 \\
<0.001 \\
\quad \text { NS }\end{array}$ & $\begin{array}{l}11 \cdot 76 \\
0.22 \\
0.24 \\
0.28 \\
0.08 \\
0.09 \\
1.80 \text { (residual) }\end{array}$ \\
\hline Total & 1763 & & & & \\
\hline
\end{tabular}

$\mathbf{n}$ is the number of positive tubes in the dilution series of the reference serum (table 2).

\section{Results}

REPRODUCIBILITY

The SDs, calculated as described, are given in table 1 . Eight of the 14 positively reacting sera were negative in more than $6 \%$ of the measurements. These negative values were disregarded in the final averaging over laboratories and sera. None of the six negative test sera was ever found positive with any test kit.

\section{ANALYSIS OF VARIANCE}

Table 3 summarizes the results. Because the mean squares cannot be regarded as a correct estimate of the variation caused by the individual factors and interactions in the experiment the variance components of the different effects were calculated from their mean squares. It can be seen that nearly all interactions are significant. This means that-for example, judgment of the quality of a kit may be affected by the serum samples in the experiment or by the laboratories reading the test, or by both. This is not an unexpected result in rheumatoid serology, where experience has already shown that the choice of the kit and of the serum samples may influence the titration end point, which is a subjective reading.

\section{DETECTION LIMITS}

The graph in the figure represents a kit with a poor performance in the low $\mathrm{IU} / \mathrm{ml}$ region as well as one with a good performance in this region. Similar graphs were drawn for every kit and their evaluation is shown in table 2 . It can be seen that the detection limits we found were generally higher than those claimed by the manufacturers.

\section{GENERAL PRACTICABILITY}

The questions mentioned under 'General design of tests' were each scored by all the participating laboratories. Table 1 gives a weighted mean score.

The positive control sera were considered separately by giving the percentage of negative scores in these sera. Unexpectedly some of these serum samples scored negatively in tests in which they should have been positive because the laboratories' own control sera did not show any irregularities. No agglutinations were found in negative control sera.

\section{INTERLABORATORY COMPARABILITY}

Table 3 shows that the variance between laboratories was less than the residual variance. Standard deviations of each of the 14 positive test sera were also calculated (data not given). The SDs were usually below the $1 \cdot 2$ dilutions found in a previous investigation. ${ }^{6}$ Standard deviations $>1$ were always obtained with serum samples having a low rheumatoid factor level $(\leqslant 25 \mathrm{IU} / \mathrm{ml})$.

\section{Discussion}

Studies such as this should enable the user of kits to make a better selection from the many kits available. Table 1 gives an overall picture of relevant properties of latex kits to facilitate such a choice. The reproducibility of the kits can be read from the SDs in this table, which show the variability of the kits within laboratories and within serum samples. The extremes differ by a factor of almost two, without a clear correlation with relative costs. Reproducibility between days may also be judged from the residual variance in table 3 , which contains the actual residue and the variance between days.

Seven kits did not detect well in the lower region $(<10 \mathrm{IU} / \mathrm{ml})$ as judged from the graphs. From the lowest readings on all test sera it would seem too that seven kits were unable to detect less than $25 \mathrm{IU} / \mathrm{ml}$. If one considers only the reference serum it seems that no more than two kits detect anything $\leqslant 25 \mathrm{IU} / \mathrm{ml}$, but this estimation is based on fewer data than the previous ones. Different clinicians may attach different importance to these figures. A limit of $7 \mathrm{IU} / \mathrm{ml}$ has been suggested in the published reports, ${ }^{10}$ but to the knowledge of the authors there is no general consensus about this problem. Although most kits seem able to detect changes from levels $>25 \mathrm{IU} / \mathrm{ml}$ to low levels and vice versa, detection of the lower levels themselves may be important. As precision of measurements tends to increase and the cost factor does not seem to be decisive (table 1) a kit with a good detecting power in the region $\leqslant 10$ $\mathrm{IU} / \mathrm{ml}$ would be a sound choice. 
The general practicability as scored in table 1 is a weighted mean of several factors. Readability is one of the most important factors. Most kits scored reasonably well here, again with no apparent relation to relative costs. The control sera presented problems in several instances where negative scores were noted in serum samples which should have been positive. In such cases the control sera were only very weakly positive, causing negative readings at the merest fluctuation. Such weak serum samples are not suitable as controls. Serum samples which have their end point in the middle of the range covered by the kit to which they belong should be selected as controls. Fluctuations in either direction can then easily be noted. Only a few control sera met this requirement.

Interlaboratory comparability should be satisfactory if readings are expressed in $\mathrm{IU} / \mathrm{ml}$ based on a suitable reference standard. ${ }^{6}$ The variance components between laboratories and between kits resulting from the analysis of variance (table 3) are both low, showing that this goal has been reached. The limits of the effect of standardisation are reached when serum samples with a low rheumatoid factor level are measured. This phenomenon is well known in rheumatoid serology.

The design of these experiments was incomplete; this diminished the work load for the participating laboratories. In future experiments of this kind reduction of the work load might be better achieved by a smaller number of repetitions on different days. Table 3 shows that the number of degrees of freedom is ample to allow this. A more balanced design results in a better analysis of variance.

Singer et al define the 'minimal detectable units' as units of the standard (or reference) divided by the titre of the standard. ${ }^{11}$ When different kits are compared, the most sensitive method available is chosen as a standard method and the results obtained with other kits are expressed in relation to this 'standard kit'. We did not adopt this method as it seemed unnecessary to establish a reference method as well as a reference serum. The procedure presented in this article is independent of any particular method and compares kits on the basis of their reading in $\mathrm{IU} / \mathrm{ml}$ on a calibrated reference serum. We also refrained from establishing acceptable variances as well as lower limits of (clinical) positivity as Singer proposed. ${ }^{12}$ By doing so we avoided interpretation of the results.

As has already been explained the use of serum pools in this study precludes assessment of any relation between the results and clinical indices. This is a subject in its own right, not necessarily connected with evaluation of the quality of test kits. Quality evaluation remains important for clinicians in order to obtain reliable and reproducible figures in diagnostic laboratory tests. This study was carried out on behalf of the Foundation Reference
Laboratory for Rheumatoid Serology (RELARES) by four Laboratory for Rheumatoid Serology (RELARES) by four laboratories under the supervision of $H$ G M Geertzen, responsibility rests with the Dutch coordination committee for quality control of clinical laboratory research, which also provided financial support. The authors wish to thank T E W Feltkamp, C Kamphorst, P C Limburg, J A M Snijder and $M L$ Westedt for constructive criticism. Particular thanks are due to $\mathrm{E}$ de Vries for his contribution to the graphical presentation.

1 Singer J M, Plotz C H. The latex-fixation test I. Application to the serological diagnosis of rheumatoid arthritis. $A m \mathcal{F}$ Med 1956; 21: 888-92.

2 Singer J M. Standardization of the latex test for rheumatoid arthritis serology. Bull Rheum Dis 1973-1974; 24: 762-9.

3 Valkenburg $\mathbf{H}$ A. Latex fixation test. In: Kellgren $\mathbf{J} \mathbf{H}$ Jeffrey M R, Ball J, eds. The epidemiology of chronic rheumatism. Vol 1. Oxford: Blackwell, 1963: 337-9.

4 Klein F, Valkenburg H A, van Zwet T L, Lafeber G J M Characterization of two different agglutinators in the latex fixation test, occurring in normal human sera. Immunology 1966; 10: 87-98.

5 Dorner R W, Alexander R L Jr, Moore T L. Rheumatoid factors. Clin Chim Acta 1987; 167: 1-21.

6 Klein F, Janssens M B J A. Standardisation of serological tests for rheumatoid factor measurement. Ann Rheum Dis 1987; 46: 674-80.

7 Klein F, Bronsveld W, Norde W, van Romunde L K J, Singer J M. A modified latex fixation test for the determination of rheumatoid factors. $\mathcal{f}$ Clin Pathol 1979, 32: $90-2$.

8 Numeric algorithmic group. GLIM-system. London: Royal Statistical Society, 1986. (Release 3, No 77.)

9 Anderson V L, McLean R A. Design of experiments, a realistic approach. New York: Marcel Dekker, 1974.

10 van Leeuwen M A, Westra J, Limburg P C, de Jong $H$ J, Marrink J, van Rijswijk M H. Quantitation of IgM-, IgA-, and IgG-rheumatoid factors by ELISA in rheumatoid arthritis and other rheumatic disorders. Scand $\mathcal{f}$ Rheumato [Suppl] 1988; 75: 25-31.

11 Singer J M, Edberg S C, Selinger M, Amram M. Quality control of the latex-fixation test. Am f Clin Pathol 1979; 72 : 591-6.

12 Singer J M, Edberg S C, Markowitz R, Glickman J D, Miller L, Marchitelli R. Performance of latex-fixation kits used for serologic diagnosis of rheumatoid factor in rheumatoid arthritis sera. Am F Clin Pathol 1979; 72: 597-603. 